\title{
Investigating morphological changes of a capital city: The case of Ankara
}

\author{
Melike Boz Günay* \\ Ayşe Sema Kubat**iD
}

\begin{abstract}
Capital cities have a major role in carrying the symbolic meanings of their countries. Planning decisions and historical periods affect their urban forms and development processes. This research examines the morphological evaluation of Ankara-the capital city of Turkey - and provides an approach to understanding its unique physical structure. Ankara has witnessed strategically important planning periods through its history that are reflected in its urban form. The historical periods affecting the developing process of the capital city are analyzed through a mathematical method called "Space Syntax" which contributes to the field of urban morphology with a quantitative perspective. The analytical framework investigates the changing process of Ankara's unique urban axis and morphological structure. Its different historical periods show that the capital city is constantly changing. Ankara's monumental city axis, which shows its traces since the formation of the city, still exists today. However, this unique axis, which connects the historical core areas of the capital city, has lost its potential today. Due to economic and political demands, the main axis, namely Atatürk Boulevard, has been replaced by a newly formed western artery. Understanding Ankara's forming and changing process will enhance its subsequent development plans. By evaluating a unique capital city from Turkey with a morphological perspective, this research will contribute an approach to future studies.
\end{abstract}

Keywords: Ankara, capital city, urban morphology, space syntax

\section{Introduction}

The phenomenon of urban change is one of the most significant issues to evaluate a city's evolving process from past to present. Planning and design decisions developed for cities are the main factors that contribute to the changing process. These strategic decisions affect the city formation on macro to micro scales. As cities develop and grow, the morphological character of the city changes and capital cities have the central role affected by this change. Capital cities have a character for being a symbol for their countries that makes them special. Each capital city in the world has different historical, economic, cultural, and political backgrounds, and the city form is evolved around the effects of these processes. Urban morphology provides a multi-disciplined research area by examining the reflections of these effects on the urban form. Through 
morphological analysis of a capital city, this research aims to understand its unique urban structure and the factors of the city's having a role as a capital.

This research focuses on Turkey's capital city-Ankara-affected by many planning and design decisions throughout its historical development process. In turn, they have brought many changes to the morphological structure of the city. This research examines whether or not the special areas that carry a distinct role in a city's becoming the capital have maintained their meaningful existence until today. The characteristic features and planning processes from past to present, which make a city unique and make it the capital, are analysed morphologically with the Space Syntax method, a special mathematical approach.

\section{Conceptual and Theoretical Background}

Urban morphology, which contributes to urban form investigation on various disciplines, is the main approach behind this research. Rapaport (1977) emphasises that city is a system that includes many economic, social, cultural, political, and historical backgrounds. As an interdisciplinary field, urban morphology has the opportunity to reflect the past and future goals of the city (Malfroy, 2004). In this context, changes in the urban form will bring about differences and transform the physical environment. Therefore, it is critical to analyze forming and developing processes of the cities and evaluate them from a morphological perspective.

Many countries in the world are known for their capital cities. Their symbolic meanings affect the city's urban character and development strategy. In capital cities, it is observed that the spatial formation of the city and the political process are interrelated issues (Lefebvre, 1991). In the historical process, the first capitals emerge as central areas representing the political system for their countries (Kılınç, 2013). In the east, countries such as Mesopotamia, India, and China, and in the western world, the same aim is observed in the establishment of many of the cities belonging to the Renaissance Period (Tankut, 1990). When the formation and development processes of capital cities in history are examined, Washington, which was founded in the late 18th century, Ankara, which was established in the first half of the 20th century, Brasilia and Islamabad, which were established after the Second World War, have been chosen as the capital cities because of political and geographical differences. However, what unites these cities at a common point is that they reflect the first urban planning processes for their countries (Kılınç, 2013).

Tankut (1990) explains the effects of economic, social, and political factors on urban form with four sample capital cities-Canberra, Ankara, Islamabad, and Brasilia-that carry the political decisions' effects on their urban structure with a striking common feature as shown in Figure 1. While the main goal in the establishment of Canberra is to be a national capital city, in Ankara, it is to create a city model that represents the Republican Period. The process of Brasilia's being a capital city is based on reflecting the economic development periods of the city. In Islamabad, the concept of nationality comes to the fore, aiming to symbolize the state.
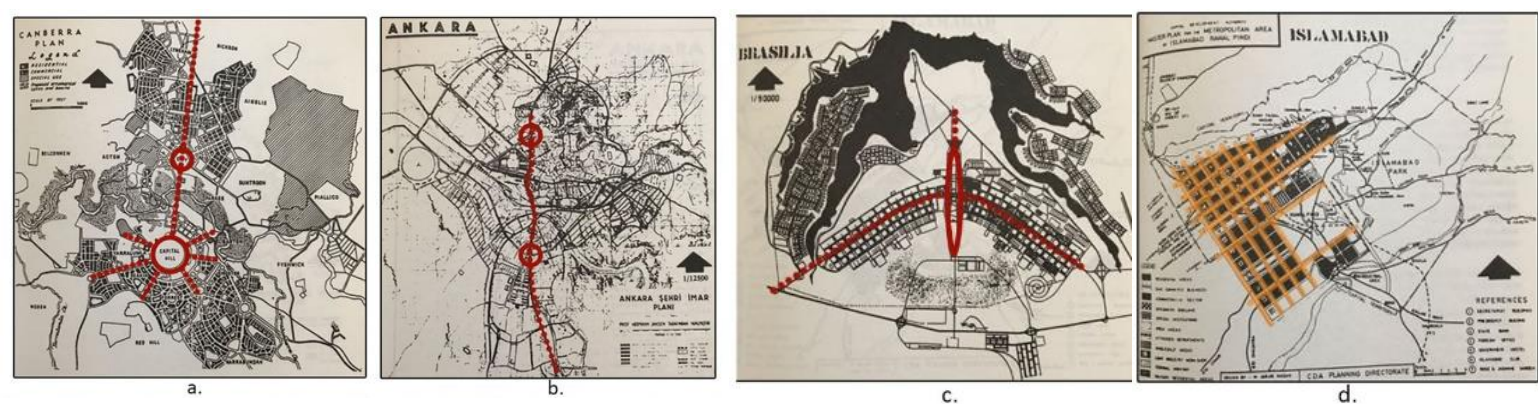

Figure 1 Plans of four sample capital cities (a. Canberra, b. Ankara, c. Brasilia, d. Islamabad; schematised by the author from Tankut, 1990).

Tankut (1990) defines the urban formation process as a nationality concept and states that the four example capital cities have a national symbol as their common feature. However, they have 
different characteristics with their locations, political systems, histories, and the capital city images they reflect. The "created center" decision can be observed in Canberra, Ankara, and Brasilia, and the striking city axis draws attention in these cities. On the contrary, this decision is not observed in Islamabad; it is an example of a multifunctional capital city and has a regular plan open to growth (Tankut, 1990, p.18). However, the political effects can be obviously observed as a common finding in these examples through the existence of a special urban axis which the city shaped itself around. The leading inference that can be made from the study of Tankut's approach is that a city's becoming a capital is shaped around the specific factors and decisions which affect the city's development process.

The other distinctive research focuses on Brasilia's morphological transformation process (Holanda et al., 2015). The Space Syntax method provides an analytical evaluation to analyze the urban system in the mentioned research. Brasilia's changing urban development phases and centrality factors have been analyzed using the Space Syntax method's parameters. It has been analyzed to what extent the urban parts that form Brasilia have an integrated structure, and the spatial structure has been analytically characterized. In addition, the urban qualities that form the central functions have been examined through Space Syntax. In the study, it has been observed that the central core of the capital city, which has been originally planned, does not carry this potential today. This result can be explained by the representation of three centres belonging to the city as shown in Figure 2: the functional centre where business and service activities are concentrated; the demographic centre that minimizes the distances of the city; the morphological centre, which is topologically the most accessible area of the city. As a result of the study, it is mathematically observed that Brasilia's main city axis and specific urban centres are in changing conditions.

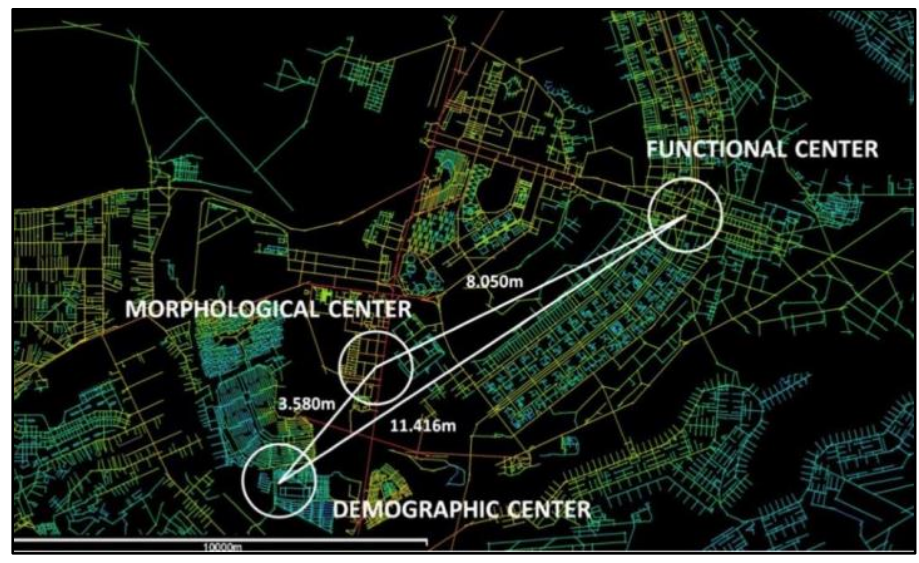

Figure 2 Deformation of Brasilia's city centres obtained by Space Syntax analysis (Holanda et al., 2015).

In this context, Turkey's capital city Ankara has a unique meaning by carrying the effects of the special historical, cultural and political process, especially from the Country's Republican Period of 1923 to today. In the light of the previous studies, this research analyses Ankara's changing urban structure and morphology.

\section{Methodology}

Analysing a city's physical structure using a holistic approach brings an evaluation of all the interacting elements within the city (Herbert \& Thomas, 2013). Kropf (2017) defines urban morphology as a representation of researching, studying, and thinking tools to understand and interpret the urban environment. Examining the morphological changing process of a capital city presents a perspective to evaluate the conditions of its historical periods.

The research proposes using Space Syntax as a tool to evaluate the planning periods affecting the historical development of Ankara. This special morphological theory-developed by Bill Hiller 
and Julienne Hanson and colleagues at $\mathrm{UCL}$ - provides a demonstrable frame to understand the urban system and its physical evolution (Kubat, 1999). The aim behind this technique is to explain the connection between the society and urban environment (Kubat, 1997). Space Syntax allows us to understand social relations and their reflections on the morphological structure (Hillier, Hanson \& Graham, 1987). By presenting a quantitative view to the analysis of the changing conditions of cities, Space Syntax is a frequently used research method (Hillier \& Hanson, 1984).

Space Syntax contributes a morphological approach to analyse the physical conditions of the city while evaluating the relationships between society and urban structure. In this study, the physical analysis of the city has been started by considering historical periods. The capital city's historical plans and documents of each determined period are converted into axial maps. Additionally, these maps, which are an axial representation of each determined historical period of the city, are converted into segment maps to analyse the city's morphological structure more accurately. These maps created from the historical plans are analysed in the Depthmap programme which allows the interpretion of the changing structure of the city with tables and graphics. Space Syntax measures the connectivity, integration, and choice values of the historical periods evaluated in the research. Thus, a comparative framework on mathematical data is presented by using various parameters in the analyses. The urban system and its spatial relations can be reached in a more understandable frame through these measurements (Hillier \& Hanson, 1984). By evaluating local (R:400, 800) and global (R:n) radii, Ankara's historical and planning periods can be observed through a comparative perspective morphologically at the city scale.

\section{Findings of the Morphological Change of Ankara}

Turkey's capital city Ankara was born in Anatolia, known as a place like a steppe (Işın, 2009, p. 11). Ankara is a special city representing the Republican period, and a cultural transmission belongs to this unique process.

The Declaration of the Turkish Republic reflects a significant period that shaped the urban character of Ankara as the capital city. Most of the studies about the capital city Ankara define the Republican period as a symbol of national identity (Bayraktar, 2016; Işın, 2009; Cengizkan, 2009) and representation of modernism. This study considers the special period as a breaking point for the evolution of Ankara's morphological structure (Figure 3 ). The historical periods analysed by the study have been shaped around this perspective. Therefore, both the urban system before the declaration of the Republic and the planning periods created after that time and the current city situation are analysed in this research.

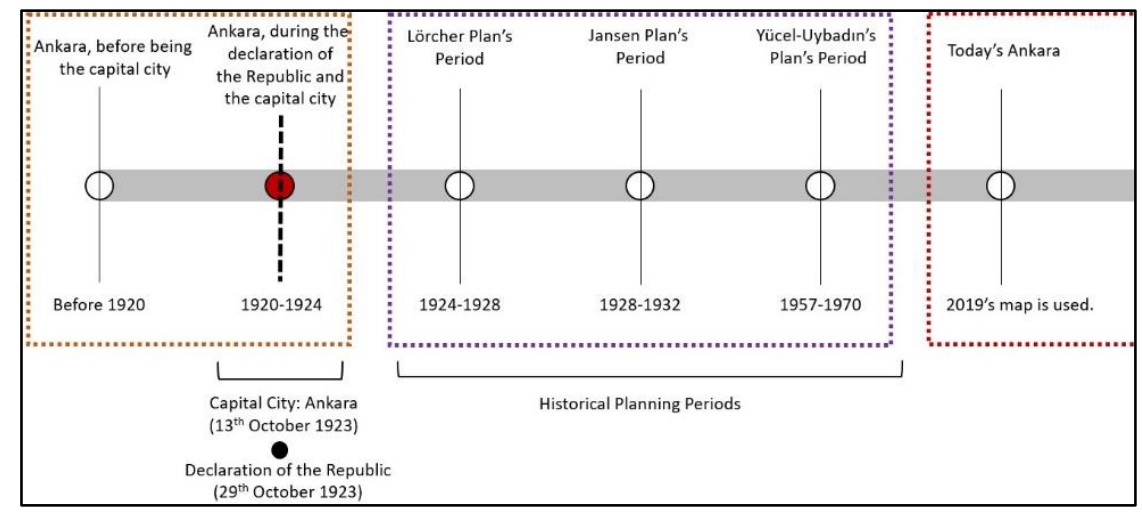

Figure 3 The historical periods examined by the study with Space Syntax method.

The data evaluated within the scope of the study are the plans of the Lörcher period (1924-28), Jansen period (1928-32), and Yücel-Uybadın Period (1957-70), the three main planning periods that affect the urban development of Ankara, and the map reflecting its current condition. Additionally, the 1839 map, which reflects the urban structure of Ankara before it became the capital, and the 1923-24 map, which represents the period when the Republic was declared, and the city was the 
capital, are analysed with their axial maps (Figure 4). In determining the maps of the mentioned periods, the reachable data is a limitation of the study. The implementation process of the study is based on the analysis of these six periods with the designed methodological frame shaped by Space Syntax (Figure 5).

Page | 133

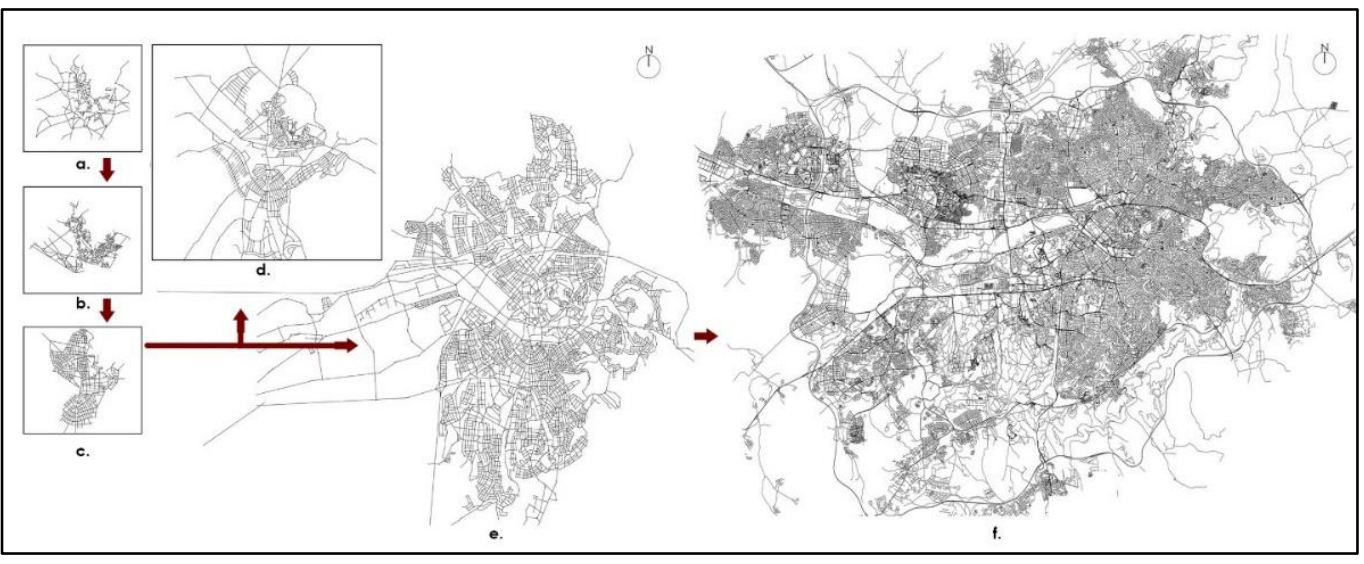

Figure 4 The axial maps of the analysed historical periods (a. 1839 map; b. 1924 map; c. Lörcher Plan; d. Jansen Plan; e. Yucel-Uybadin Plan; f. Today Ankara).

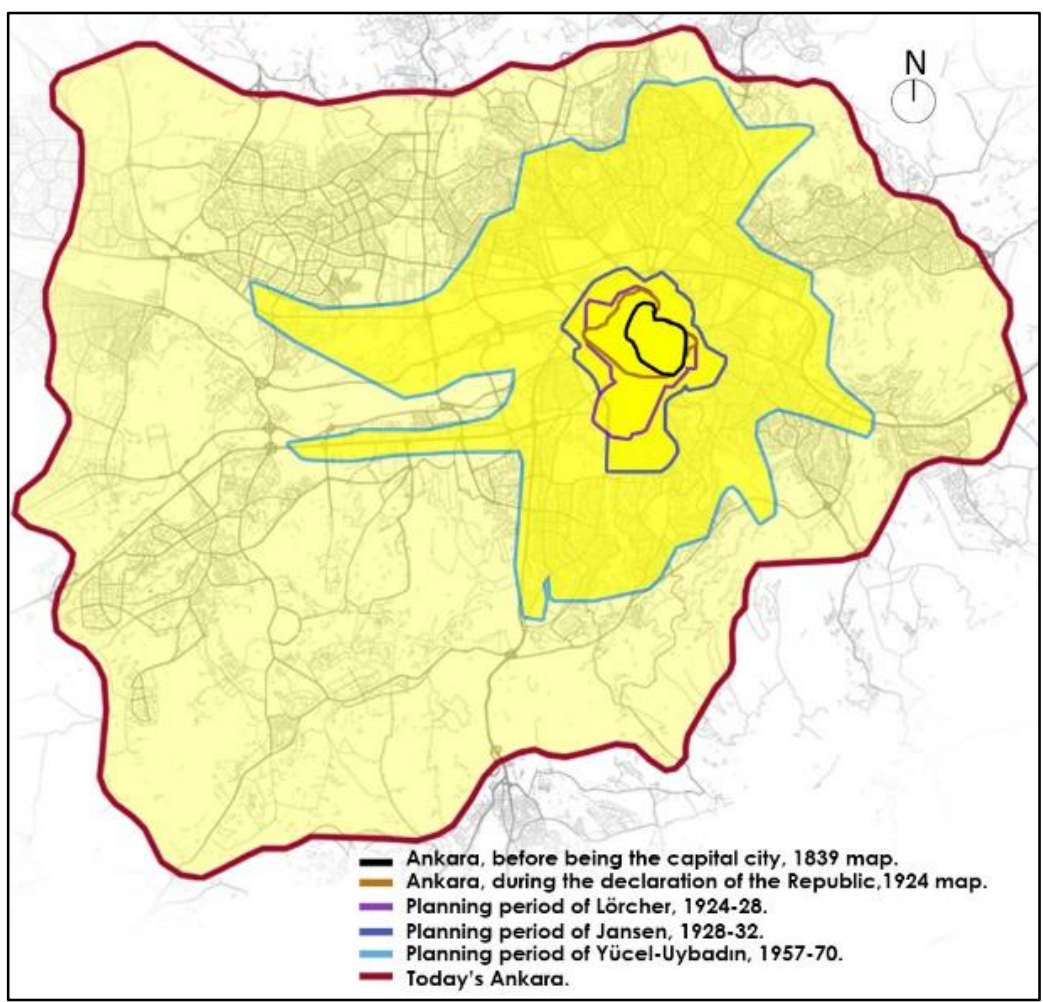

Figure 5 The city boundaries of the six periods analysed.

\subsection{Historical periods}

The first map evaluated within the analysis of the study belongs to the year 1839 and has a critical role in that it reflects the first known borders of Ankara (Cengizkan, 2009). This historical map contains the first traces of Ankara's macro form shaped by its geomorphological urban structure. When this map is analysed spatially, Ankara is surrounded by castle walls in the historical period before it became the capital city, and an organic pattern of structure is observed (Figure 6). The settlement was shaped around the Ankara Castle, and the circulation in the city can be described with thin and long roads. 


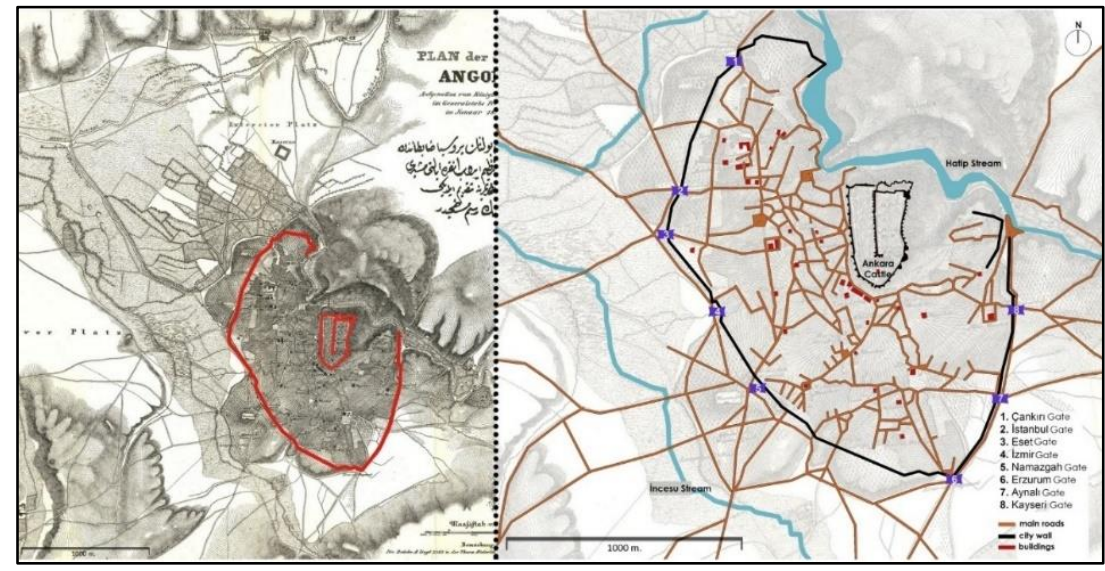

Page | 134

Figure 6 The 1839 map \& its spatial analysis.

By the 1920s, the process of Ankara being the capital city and the declaration of the Turkish Republic brought about the necessity of phases to be taken for the physical condition of the city and planning decisions. The first preparation in this period was to develop the city's growth opportunities with the Ankara Castle and its surroundings, which represent the city's historical centre. The 1924 map has a significant role in reflecting the urban system as a map during the period when Ankara was the capital city. It is an inevitable process that the effects of the developing new administrative period will directly reflect on the morphological structure of the city. This map's spatial analysis provides information about the growth directions of the city and the traces of the new representation spaces reflecting the Republican period (Figure 7). In the 1924 map, a representative urban axis can be observed. This unique axis is Atatürk Boulevard (known as Bankalar Street in that year), connects the old and new city and reflects the Republican period (Keskinok, 2009). In these years, the city needs to experience development on the axis of Atatürk Boulevard, especially while the location selections for the new buildings relating to the Republican period were made. This unique urban axis is essential in connecting the old and new centres of the city. Additionally, it has a significant role in reflecting the capital city's economic, social, cultural, and historical transformation. Atatürk Boulevard is evaluated as a strategically important city axis for this research.

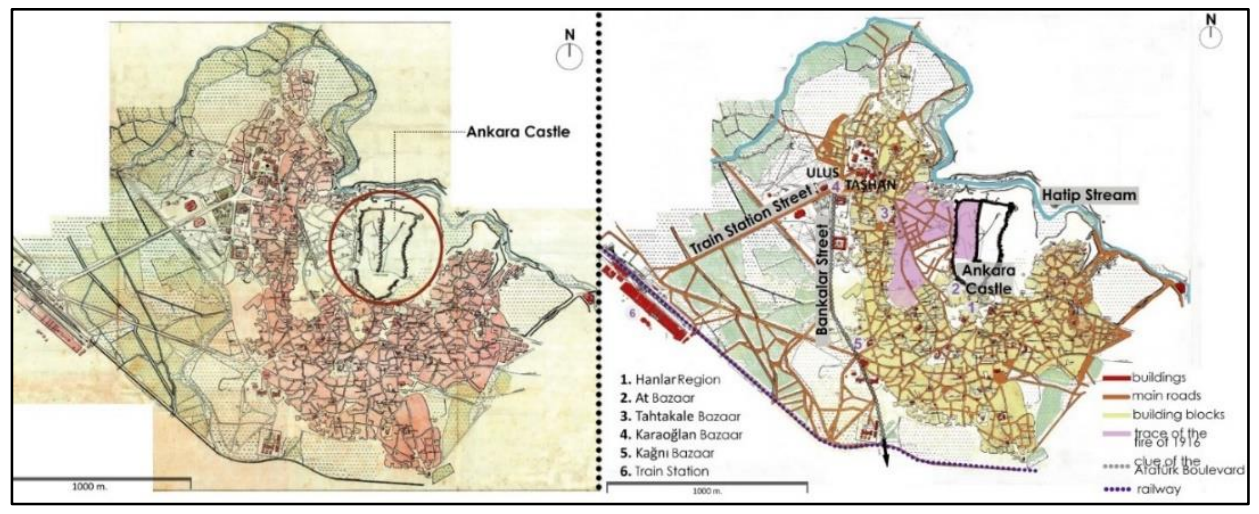

Figure 7 The 1924 map \& its spatial analysis.

Lörcher's Planning period (1924-28) shows the first planning decisions of the capital city Ankara. This plan's decisions include growth strategies in the south of the city, Ulus representing the old city, and Kizılay representing the new city in the direction of growth emphasised (Figure 8). In these planning decisions, historical buildings reflecting the Republican period have been located in Ulus, while the Kızılay region houses the administrative units. The urban element that provides a strong connection between these two city centres is Atatürk Boulevard. In this period, the city's morphology was formed by the streets, squares, and regions around the boulevard. 
Page | 135

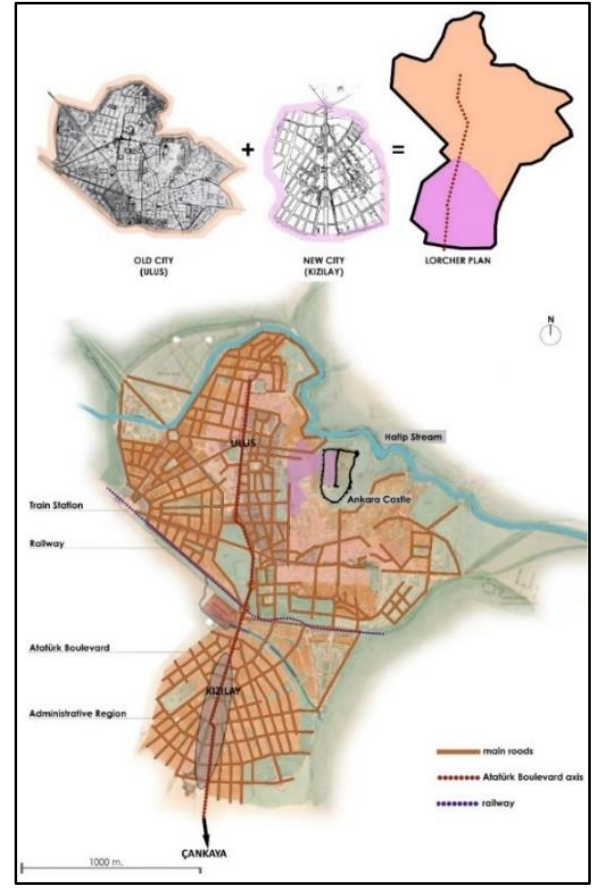

Figure 8 Lörcher's Planning Period (1924-28) \& spatial analysis.

Jansen Planning decisions (1928-32), which continue the traces of the Lörcher Plan, were put into practice with international competition. This period proposes the strategy of zoning in the city regions. Jansen's planning approach concentrates on the idea of the development of the urban system on Atatürk Boulevard. The role of Atatürk Boulevard as a bridge between the old and the new city centres became more striking in this period. Also, the cultural, educational, and administrative buildings were located on this monumental axis. Considering the spatial analysis of this period, Ankara's main growth direction has been determined towards Çankaya in the south. However, Ankara Castle has been used as a representation symbol in the Ulus region, the old city centre, and new constructions have been settled there (Figure 9). Jansen's emphasis on preserving the traditional pattern of the city by considering the old and new city centres together in the urban planning decisions also carries clues about which processes play a role in the change of the morphological structure of the capital city. In this context, the monumental Atatürk Boulevard axis had a strategic position. In contrast, the core regions of the city have been extended from Ankara Castle to Çankaya direction with a preservative approach for this period.

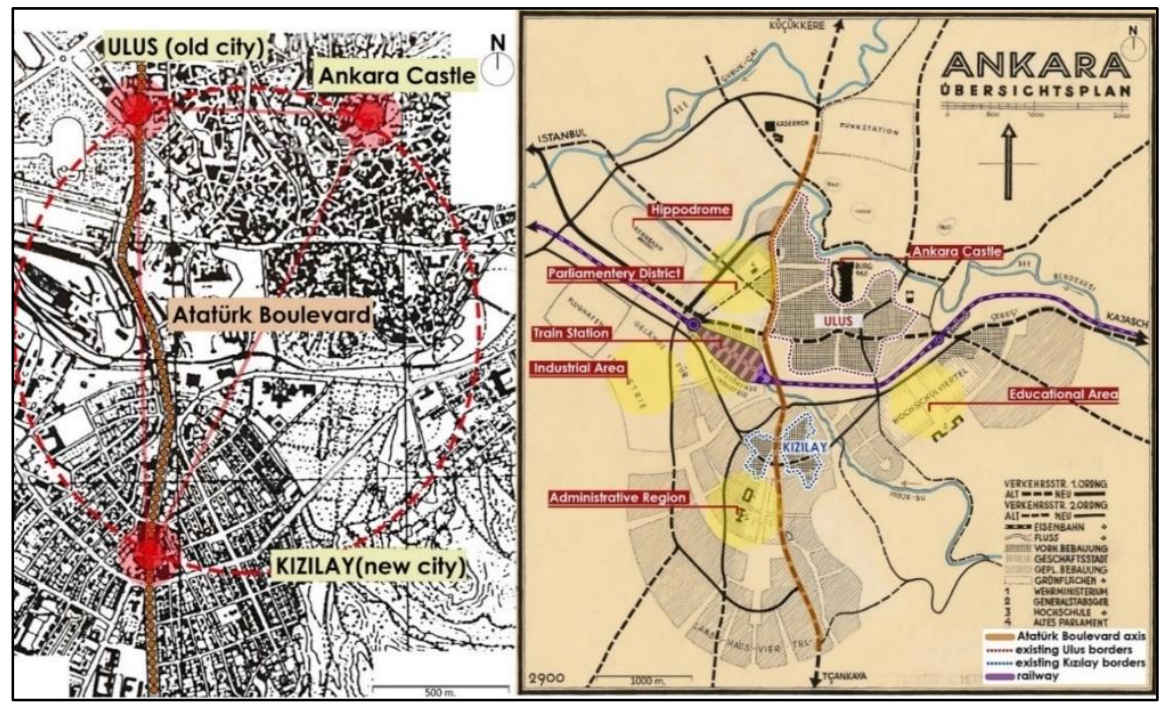

Figure 9 Jansen's Planning Period (1928-32) \& spatial analysis. 
Yücel-Uybadın Plan (1957-70) has been implemented as a result of an international competition at a time when the population of the capital city increased considerably. This period aimed to prevent urban sprawl with this plan, which was created to control the increasing population (AMM, 2006). However, the unpredictable population growth led to illegal buildings in the city (Figure 10). This planning period had been created when the rate of urban development and the increasing population was high and became a period when the number of buildings and parcels increased throughout the city compared to the previous Jansen period. Because of this condition, the number of buildings and parcels has increased throughout the whole city compared to the previous Jansen period. Günay (2006) states that this period did not have the form-seeking approach of the Jansen and Lörcher planning periods. It is generally thought that this period had not strategically directed the development of a capital city.

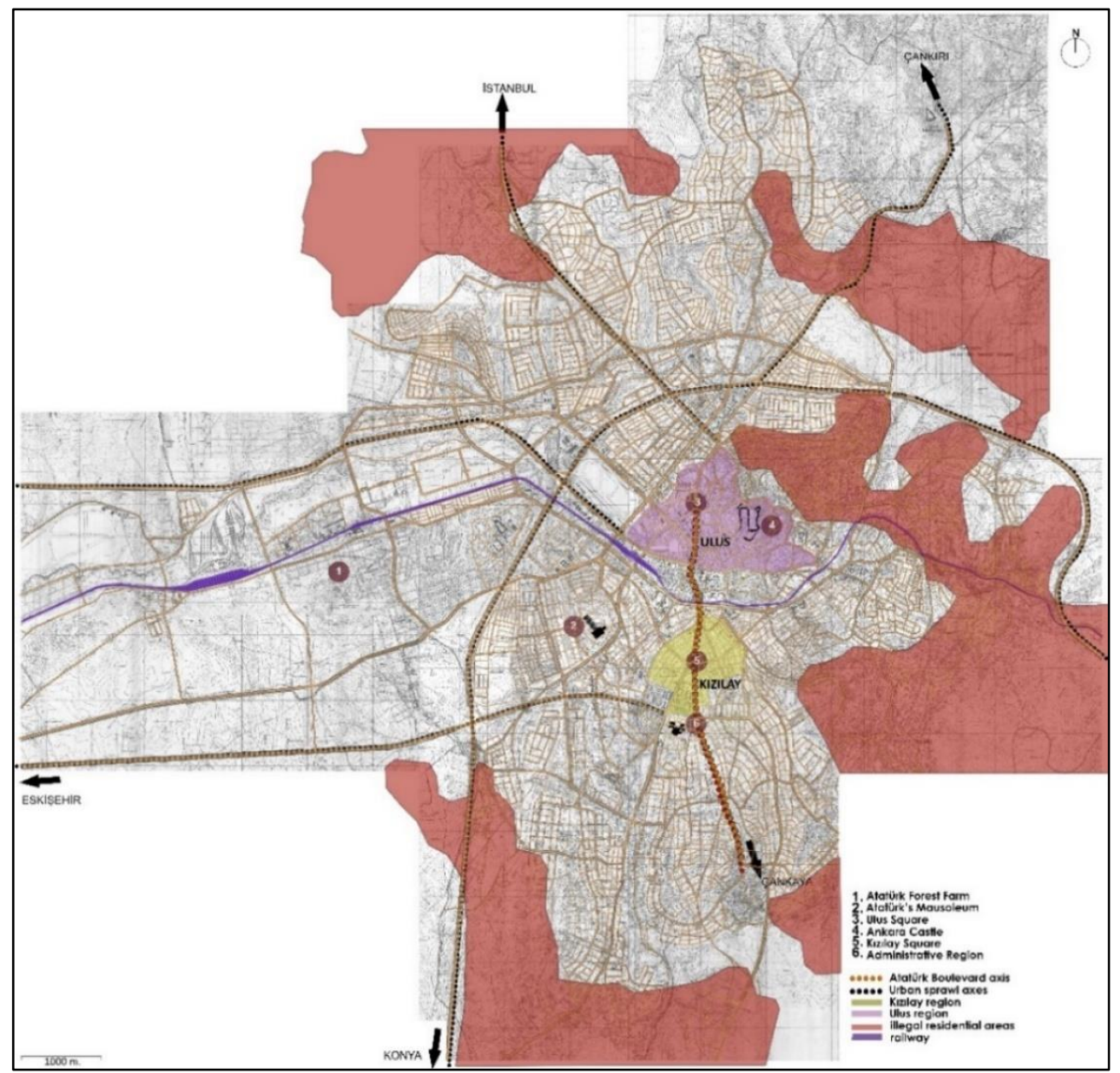

Figure 10 Yücel-Uybadın's Planning Period (1957-70) \& spatial analysis.

Since the 1970s, the development in the urban model has affected the city as an uncontrolled growth process. Essentially, since the Jansen Plan, the need for a comprehensive master plan has been emphasised (Günay, 2006). For this purpose, the 1990 master plan has been developed, which has the effects of the current urban system of Ankara (Figure 11). An increased urban circulation axis and many interaction arteries are observed in current Ankara's urban morphology. It can be concluded that the effective potentials of the old city centres Ulus and Kızllay have decreased when today's condition is evaluated within the uncontrolled growth process of the city (Figure 12). Especially since the 2000s, increasing shopping malls, high-rise offices, and residential blocks and the problem of scale disorder in the city have become factors affecting the morphological structure of the city. 
Page | 137

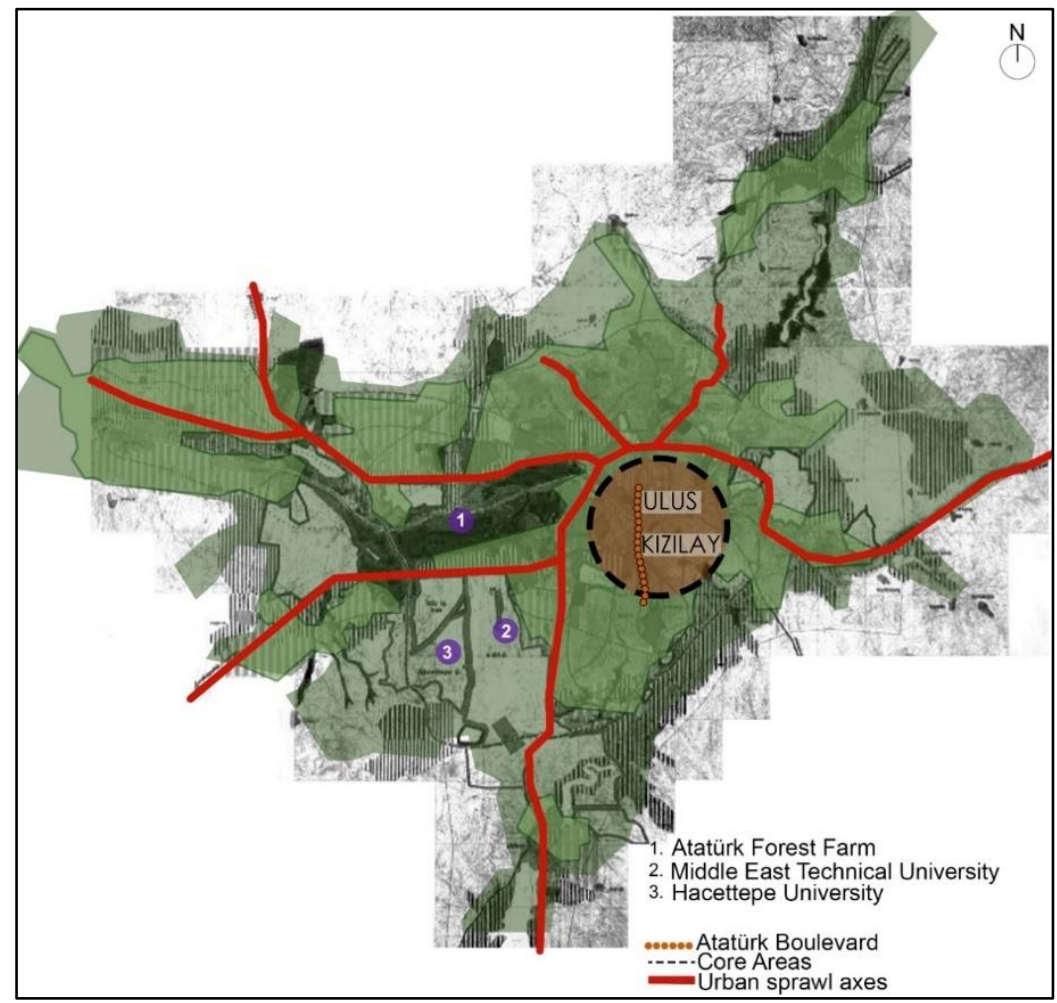

Figure 111990 Master Plan.

By evaluating the distinctive planning decisions and historical periods of the capital city Ankara, the morphological structure of the city's changing process is observed with historical maps and images. As a result of these observations, it is deduced that Ankara's urban system is shaped by the effect of its geomorphological features, and the central core areas emphasise its capital city character. Atatürk Boulevard, which is the main urban element in the capital city, has shown its potential throughout all periods as a monumental city axis. However, it is concluded that the existence of this axis in the historical periods has gradually lost its strong character due to the appearance of different city axes. The most critical milestones of examined different periods are explained in Figure 13.

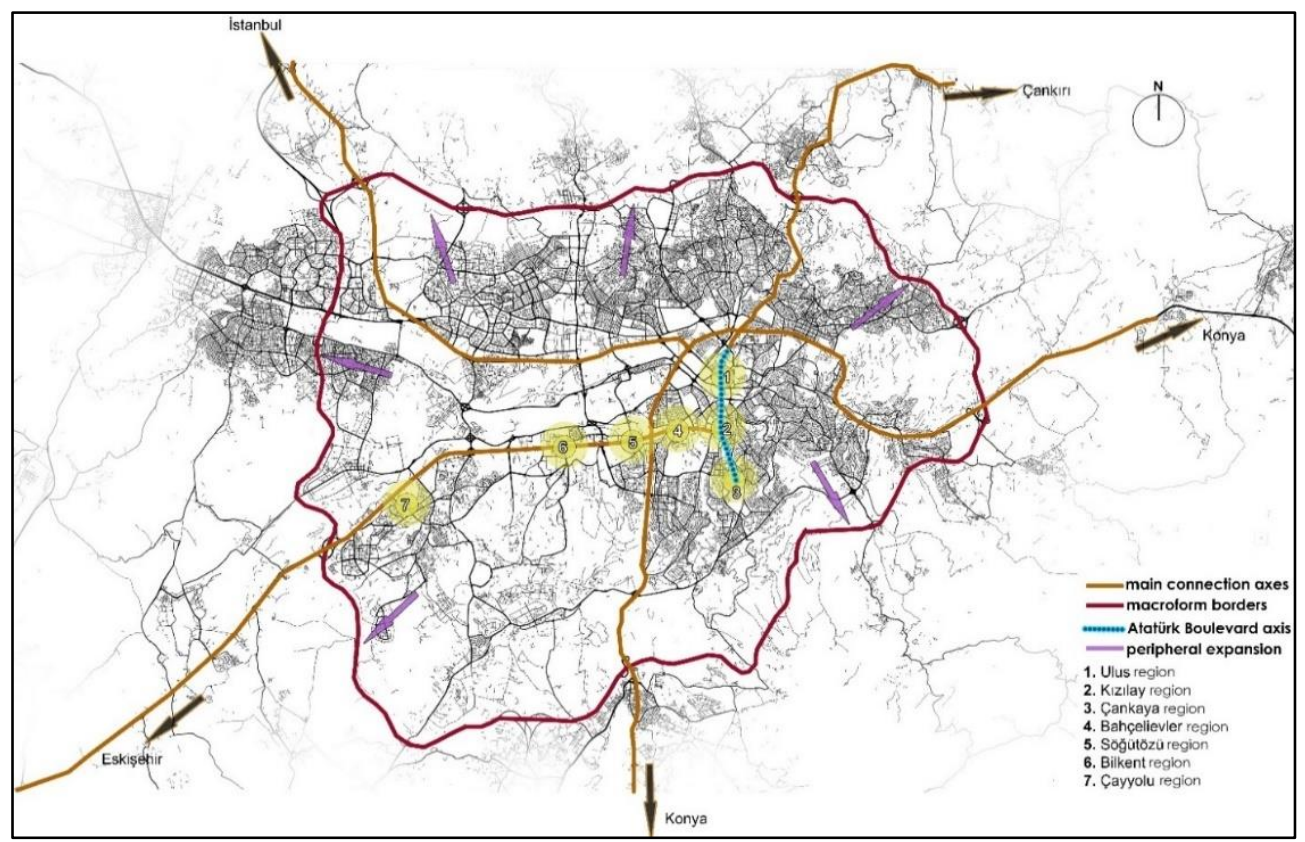

Figure 12 Today Ankara \& spatial analysis. 


\begin{tabular}{|c|c|c|c|c|c|c|}
\hline & $\begin{array}{l}\text { Before being } \\
\text { the capital city } \\
\text { (1839 Map) }\end{array}$ & $\begin{array}{c}\text { During the declaration } \\
\text { of the Republic } \\
\text { (1924 Map) }\end{array}$ & $\begin{array}{l}\text { Planning Period } \\
\text { of Lörcher } \\
(1924-28)\end{array}$ & $\begin{array}{l}\text { Planning Period } \\
\text { of Jansen } \\
(1928-32)\end{array}$ & $\begin{array}{l}\text { Planning Period } \\
\text { of Yucel-Uybadin } \\
(1957-70)\end{array}$ & $\begin{array}{l}\text { Today } \\
\text { Ankara }\end{array}$ \\
\hline 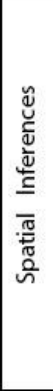 & $\begin{array}{l}\text { - city walls } \\
\text {-commercial areas } \\
\text {-organic pattern } \\
\text { - Ankara Castle } \\
\text { - Ulus region as } \\
\text { symbolized } \\
\text { core area }\end{array}$ & $\begin{array}{c}\text { - Ankara Castle } \\
\text { - Train Station } \\
\text { - commercial areas } \\
\text {-Atatürk Boulevard } \\
\text { traces (known as } \\
\text { Bankalar Street) } \\
\text { - traces of the new } \\
\text { direction } \\
\text { to the south }\end{array}$ & $\begin{array}{l}\text { •old city: Ulus } \\
\text { new city: Kızılay } \\
\text { - connection } \\
\text { between } \\
\text { the old and } \\
\text { the new city } \\
\text { (Atatürk Boulevard) } \\
\text { - railway }\end{array}$ & $\begin{array}{l}\text {-zoning decisions } \\
\text { - city triangle = } \\
\text { Ulus (old city) - } \\
\text { Kızılay (new city) - } \\
\text { Ankara Castle } \\
\text {-Atatürk Boulevard } \\
\text { as a bridge between } \\
\text { old and new city }\end{array}$ & $\begin{array}{c}\text { - urban sprawl } \\
\text { - decreasing } \\
\text { potential } \\
\text { of the Atatürk } \\
\text { Boulevard } \\
\text {-new city directions } \\
\text { mostly to the west } \\
\text {-increasing } \\
\text { buildings } \\
\text { and parcels }\end{array}$ & $\begin{array}{l}\text { •growing } \\
\text { macroform } \\
\text { •new city } \\
\text { centres } \\
\text {-decreasing } \\
\text { potential } \\
\text { of the Atatürk } \\
\text { Boulevard } \\
\text { strengthening } \\
\text { of the } \\
\text { west axis }\end{array}$ \\
\hline
\end{tabular}

Figure 13 The spatial effects of the examined periods on the city.

\subsection{Application of the method}

Space Syntax analyses aim to explain the urban change affected by the planning decisions and historical periods in the capital city's morphology with an analytical approach. Axial maps are created of all examined periods, and then each period is evaluated comparatively with mathematical parameters to explain the changing process of Ankara.

While the total number of axes is 364 in the 1839 map representing Ankara before it became the capital city, the total number of axes is 613 in the 1924 map reflecting the period when Ankara was declared the capital city. In both maps, it can be observed that the city has been formed on the same axis. On the 1839 Map, the longest axis in the city is $726.66 \mathrm{~m}$., and it was the connection that provided access to the Namazgah Gate, which is located outside the city wall. On the 1924 map, the longest axis in Ankara is $1731.86 \mathrm{~m}$. It has been determined that it connects the city to the train station and the surrounding city. In the Lörcher Period (1924-28), the first planning experience of the city and the connection of the old centre to the new centre has been put forward; the total number of axes was 380. According to the 1924 Map, the value of almost half has a striking result. This decrease is the many organic streets in the 1924 Map, especially around the Ankara Castle, and the planning of the street layouts in the city with longer viewing distances. However, during the Lörcher Plan Period, the longest axis was $1399.54 \mathrm{~m}$. It is observed that Atatürk Boulevard stands out as the connection line of the old and new city with its syntactic value. During the Jansen Plan Period (1928-32), the total number of axes increased to 830, and the longest axis was $2630.43 \mathrm{~m}$. It was the line designed as one of the leading transportation links descending from the outer periphery of the city to Ulus. The existence of Atatürk Boulevard in this period is still remarkable, but it did not show the feature of being the longest line due to the interruption of the axis on the connection points between the viewing distances. In the Yücel-Uybadın Period, when the urban growth rate increased, the total number of axes was 3928 , and today it has reached 23177 . These values are shown in Table 1.

Table 1 Quantitative analysis of axis, segment and connectivity.

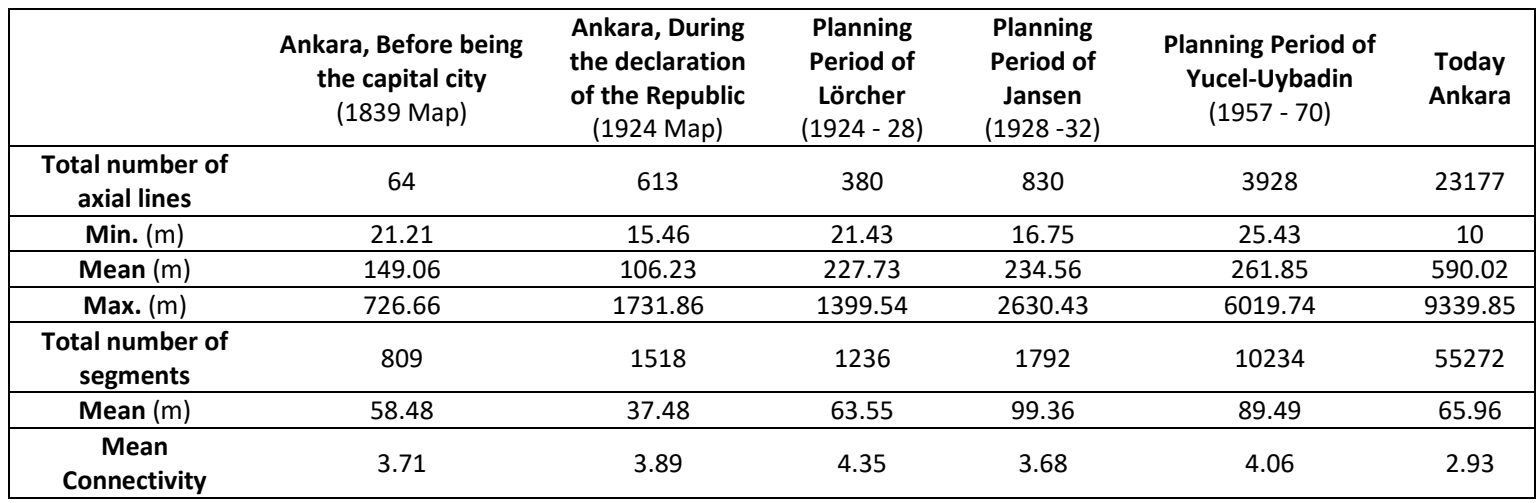


By focusing on the connectivity values, which are used to measure the degree of connection of each line with others from the axial maps, it is observed that the streets with the lowest connection are located in Ulus, which represents the historical city (Figure 14). On the other hand, Atatürk Boulevard has maintained its potential by having the highest degree of connectivity in all periods. This considerable result strengthens the role of Atatürk Boulevard as the city's main artery. However, the connectivity values of the central points located on the monumental axis Atatürk Boulevard have lost their strong character today.

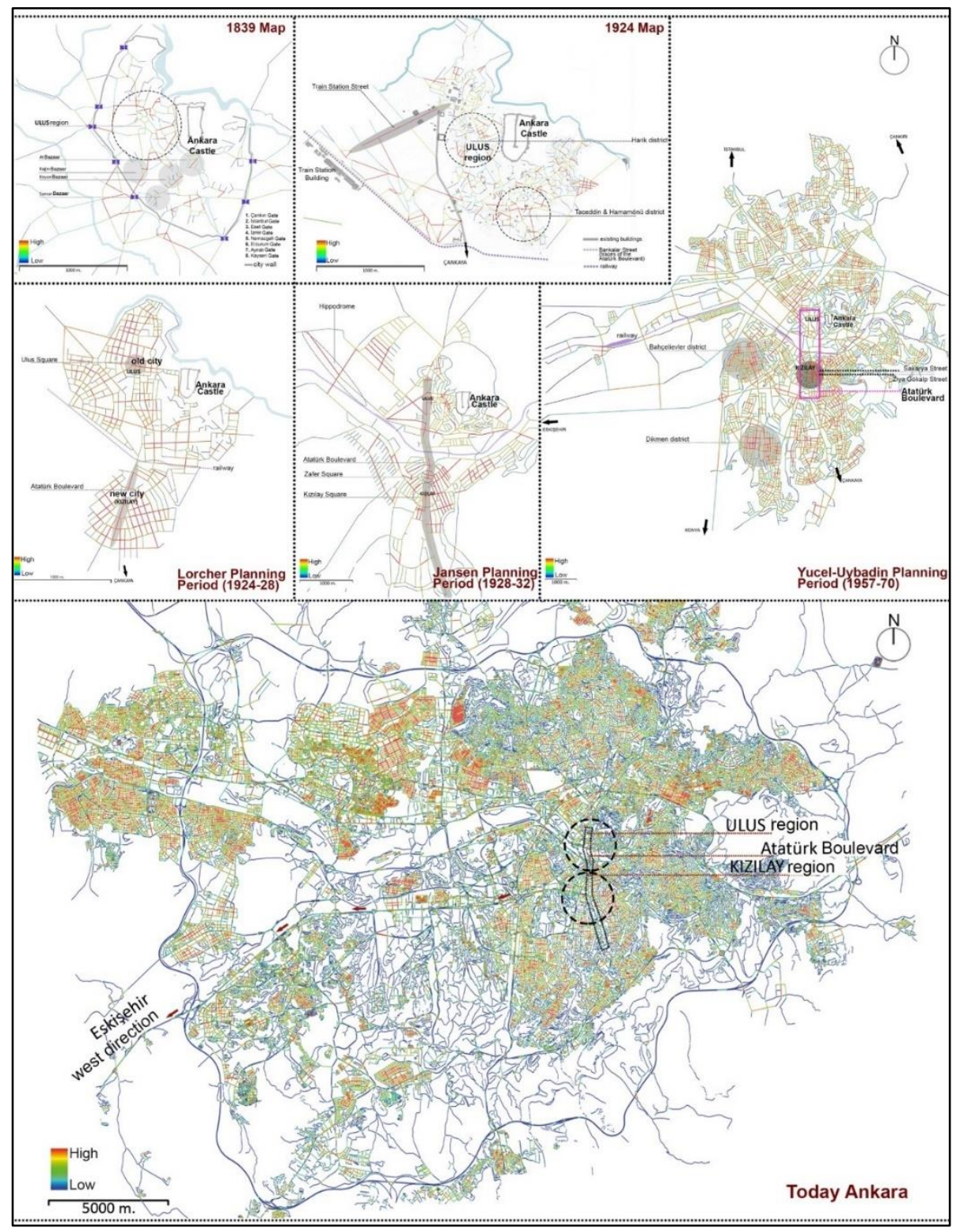

Figure 14 Connectivity maps.

The integration measurements of the examined periods from the segment maps, global and local values that give information about the accessibility values of each network at different scales have been examined (Table 2). In global integration ( $\mathrm{Rn}$ ) analysis, a high value means high accessibility, while in local measurement, the accessibility values of walking distances are reached (Al_Sayed et al., 2014). It is observed in the analysis of global integration values that as the city has growth points, the values of Ankara Castle and its surroundings in Ulus, which represents the old city, decrease. This situation gives clues about the morphological development process of the capital city. As shown in Figure 15, it is determined that Atatürk Boulevard continued its strong role until the Yucel-Uybadın Plan Period, but in this period, there is a decrease in its potential with the 
existence of the western corridor, which is a new transportation axis. It is determined that the integration values of the central cores of the city have decreased as it came to today's condition at both the global and local scales.

Table 2 Global and local integration values of the historical periods.

\begin{tabular}{|c|c|c|c|c|c|c|c|}
\hline & & $\begin{array}{c}\text { Ankara, Before } \\
\text { being the capital } \\
\text { city } \\
\text { (1839 Map) }\end{array}$ & $\begin{array}{c}\text { Ankara, During } \\
\text { the } \\
\text { declaration of } \\
\text { the Republic } \\
\text { (1924 Map) }\end{array}$ & $\begin{array}{l}\text { Planning } \\
\text { Period of } \\
\text { Lörcher } \\
(1924-28)\end{array}$ & $\begin{array}{l}\text { Planning } \\
\text { Period of } \\
\text { Jansen } \\
(1928-32)\end{array}$ & $\begin{array}{c}\text { Planning Period } \\
\text { of Yucel-Uybadin } \\
(1957-70)\end{array}$ & $\begin{array}{c}\text { Today } \\
\text { Ankara }\end{array}$ \\
\hline \multirow{2}{*}{$\begin{array}{c}\text { Global } \\
\text { Integration } \\
(\mathrm{Rn})\end{array}$} & Min. & 0.29 & 0.38 & 0.46 & 0.31 & 0.46 & 0.2 \\
\hline & Mean & 0.61 & 0.64 & 1.03 & 0.85 & 0.9 & 0.77 \\
\hline \multirow{2}{*}{$\begin{array}{c}\text { Local } \\
\text { Integration } \\
(\mathrm{R} 400)\end{array}$} & Mean & 1.22 & 1.02 & 1.03 & 1.31 & 1.33 & 1.19 \\
\hline & Max. & 2.66 & 2.35 & 2.08 & 3.42 & 3.04 & 3.07 \\
\hline \multirow{3}{*}{$\begin{array}{c}\text { Local } \\
\text { Integration } \\
(\mathrm{R} 800)\end{array}$} & Min. & 0.32 & 0.43 & 0.43 & 0.26 & 0.44 & 0.35 \\
\hline & Mean & 0.95 & 0.82 & 1.27 & 1.09 & 1.17 & 1.04 \\
\hline & Max. & 1.75 & 1.9 & 2.04 & 2.86 & 2.5 & 2.89 \\
\hline
\end{tabular}

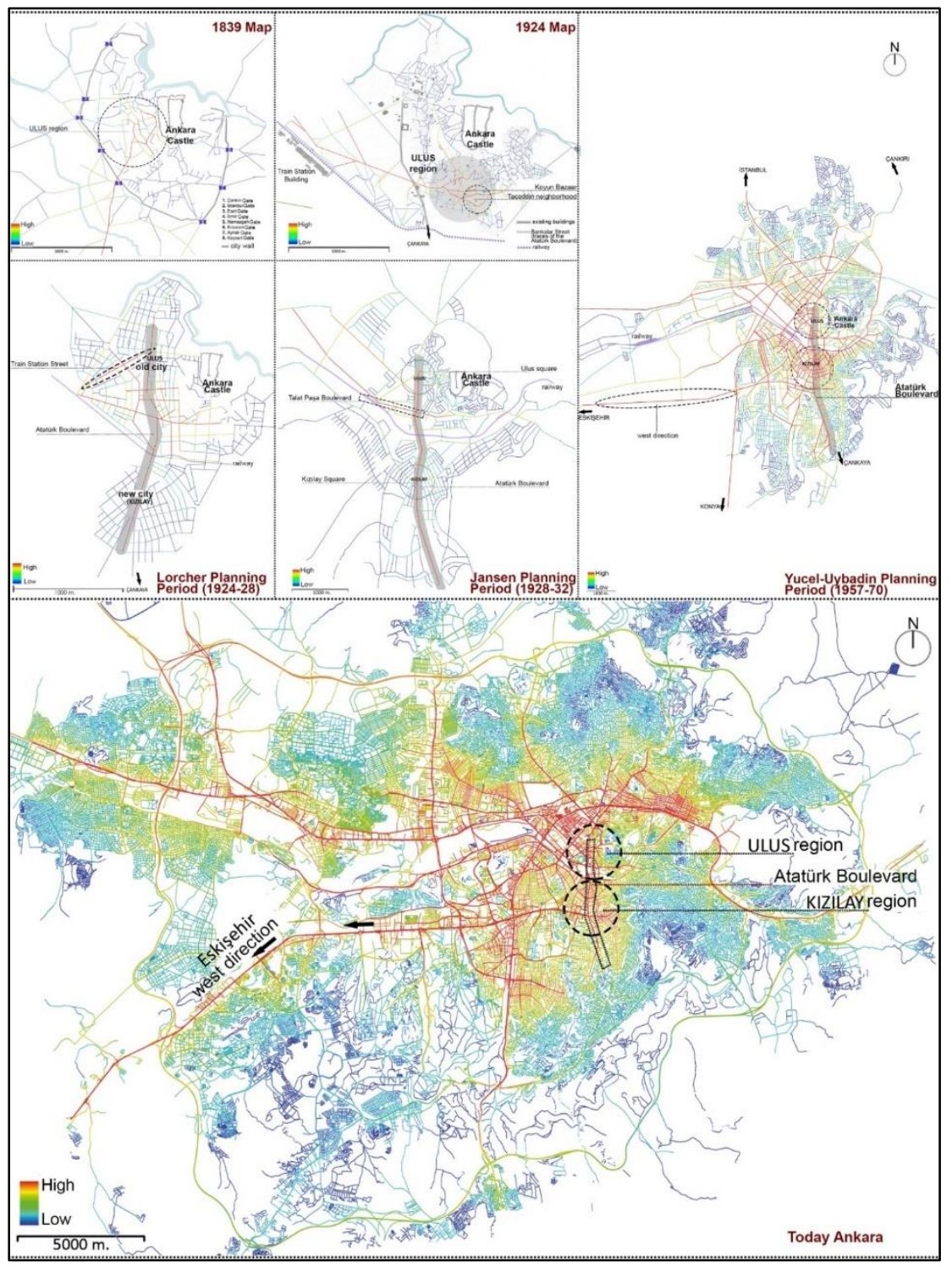

Figure 15 Global Integration (Rn) maps.

For the six evaluated historical periods, the choice parameter, which investigates the preferability level of the street networks in the urban system, has also been analysed at global (Rn) 
and local scales (R400 and R800) (Table 3). In the 1924 map, when Ankara was declared the capital city, the area with the highest global choice value is in Ulus. As the periods progressed, it is determined that the choice level of Ulus was replaced by Kızılay (Figure 16). A significant result observed here is that the global choice level of the western corridor, which is the new axis showing its existence in the Yucel-Uybadin Plan Period, has a low result. This striking result showed itself with the same findings at local scales. In line with this result, the western artery does not have the same potential as the monumental Atatürk Boulevard in terms of its structural components and connection to the city.

Table 3 Global and local choice values of the historical periods.

\begin{tabular}{|c|c|c|c|c|c|c|c|}
\hline & & $\begin{array}{c}\text { Ankara, Before } \\
\text { being the capital } \\
\text { city } \\
\text { (1839 Map) }\end{array}$ & $\begin{array}{c}\text { Ankara, During } \\
\text { the declaration } \\
\text { of the Republic } \\
\text { (1924 Map) }\end{array}$ & $\begin{array}{l}\text { Planning } \\
\text { Period of } \\
\text { Lörcher } \\
(1924-28)\end{array}$ & $\begin{array}{c}\text { Planning } \\
\text { Period of } \\
\text { Jansen } \\
(1928-32)\end{array}$ & $\begin{array}{c}\text { Planning Period of } \\
\text { Yucel-Uybadin } \\
(1957-70)\end{array}$ & $\begin{array}{c}\text { Today } \\
\text { Ankara }\end{array}$ \\
\hline \multirow{2}{*}{$\begin{array}{c}\text { Global } \\
\text { Choice (Rn) }\end{array}$} & Mean & 0.86 & 0.85 & 0.95 & 0.89 & 0.9 & 0.86 \\
\hline & Max. & 1.52 & 1.52 & 1.57 & 1.56 & 1.53 & 1.53 \\
\hline $\begin{array}{l}\text { Local } \\
\text { Choice } \\
\text { (R400) }\end{array}$ & Max. & 1.52 & 1.44 & 1.45 & 1.87 & 1.48 & 1.62 \\
\hline \multirow{3}{*}{$\begin{array}{l}\text { Local } \\
\text { Choice } \\
\text { (R800) }\end{array}$} & Min. & 0.001 & 0.001 & 0.001 & 0.001 & 0.001 & 0.001 \\
\hline & Mean & 0.89 & 0.9 & 1.01 & 0.93 & 0.99 & 0.94 \\
\hline & Max. & 1.52 & 1.41 & 1.43 & 1.73 & 1.56 & 1.67 \\
\hline
\end{tabular}

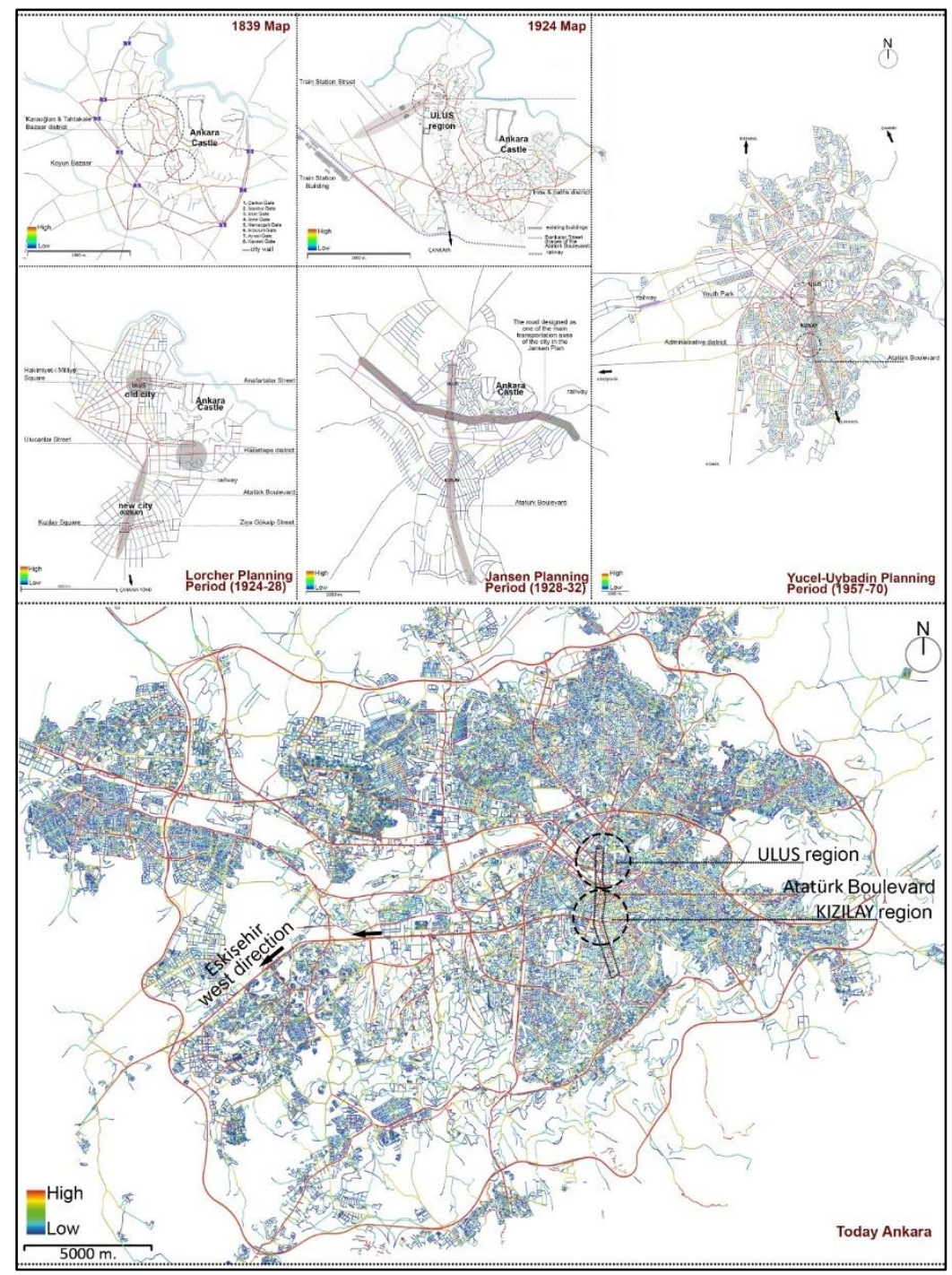

Figure 16 Global Choice (Rn) maps. 
In the Space Syntax analysis, historical periods are examined, and the places that gave Ankara the role of being the capital city are determined in a quantitative framework. When the city is evaluated holistically, the historical core areas located on the monumental Atatürk Boulevard axis still have potential for Ankara. However, as the city grew and developed, the growth direction of the city changed, and new spatial constructs emerged in the westerly direction (Figure 17).

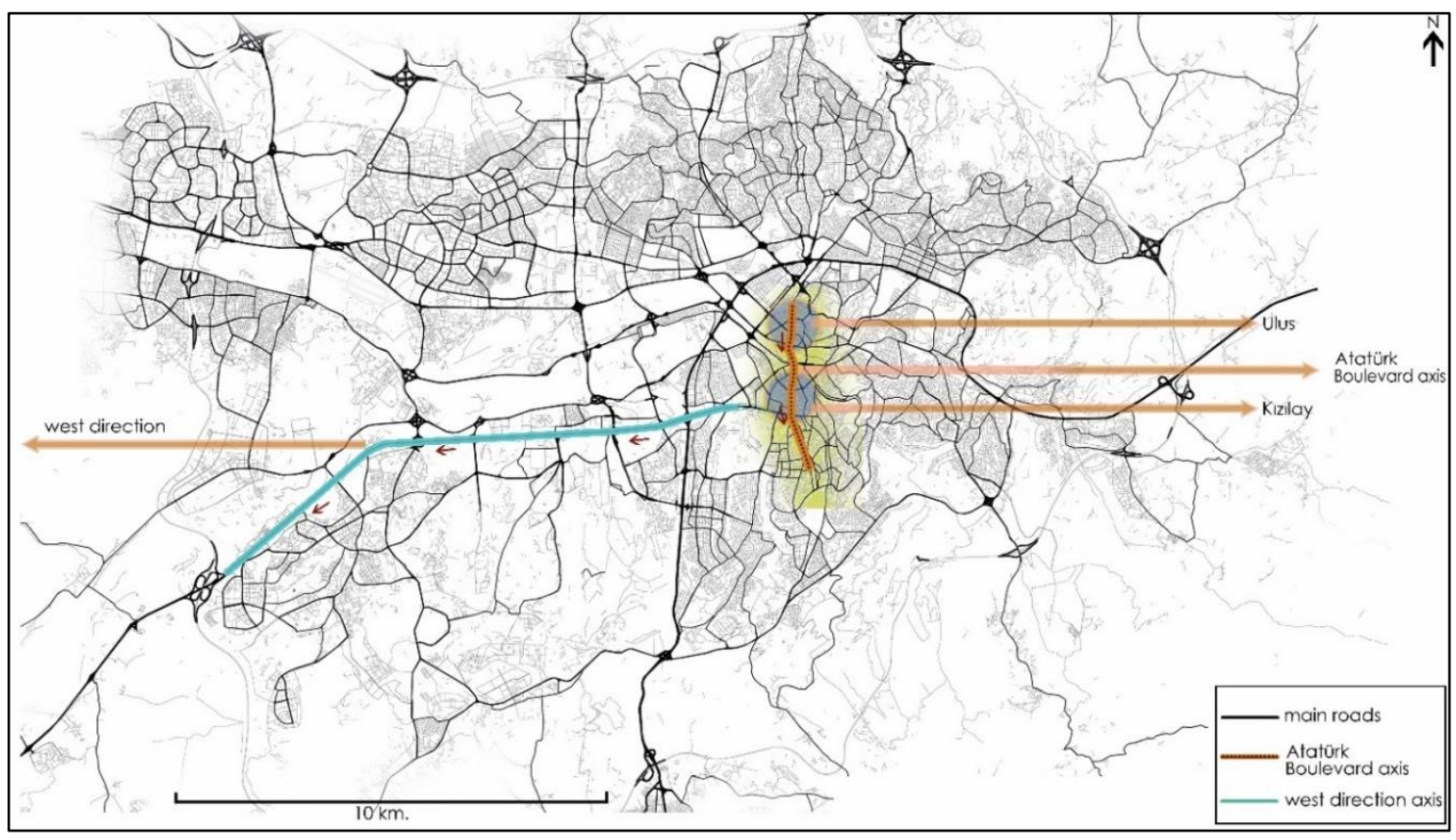

Figure 17 The evaluation of Ankara's current condition.

According to the analysis of the periods affecting the city, it can be concluded that the effectiveness of the symbolic areas of Ankara is decreasing when it comes to the present day. Although each period has main effective characteristic areas, these definitions differ as the periods progress. Space Syntax analyses have greatly contributed to distinguishing this observation. The physical reflections of the examined periods, which affect the morphological structure of the city, as a result of overall findings obtained from Space Syntax analysis are shown in Figure 18. 


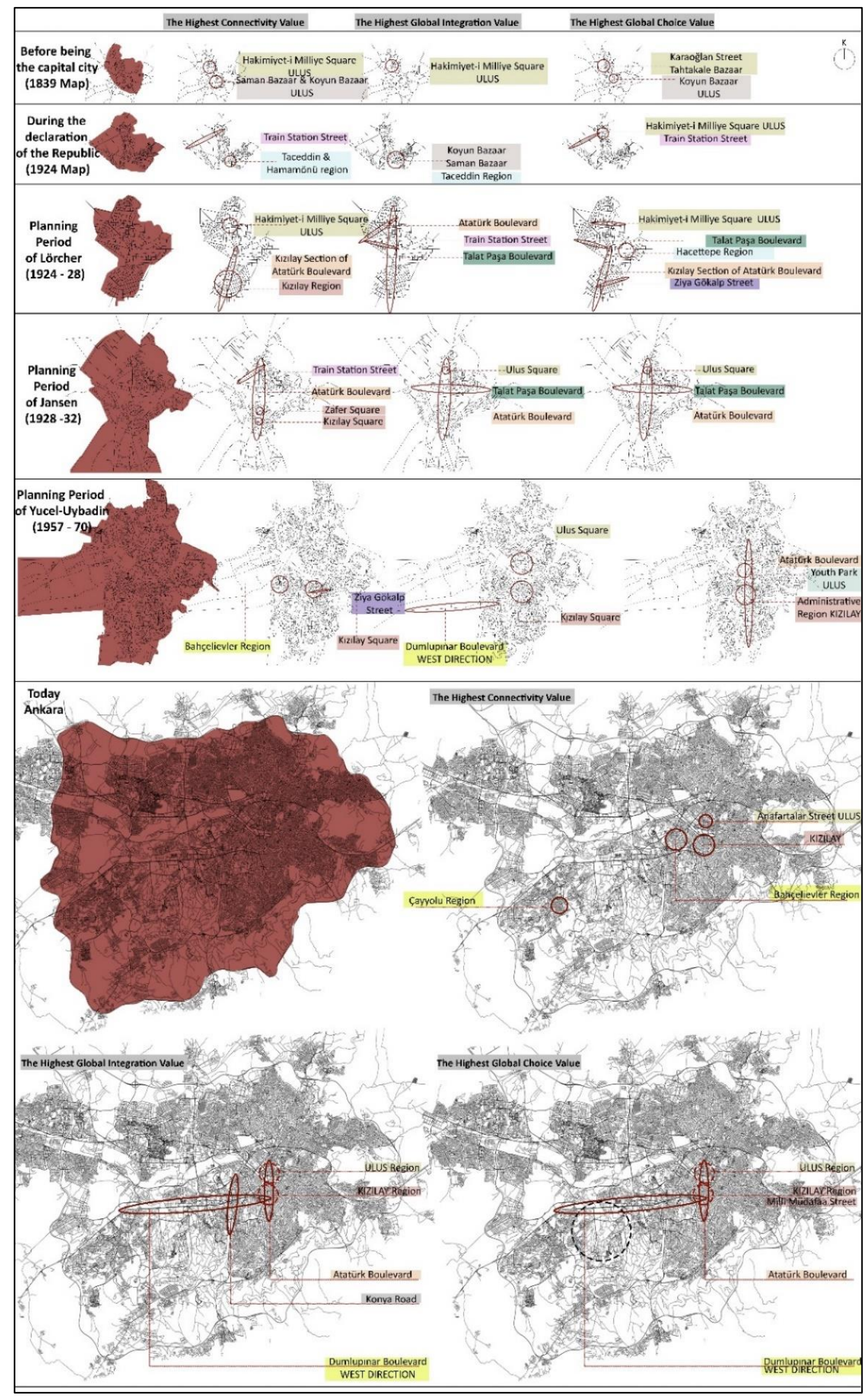

Figure 18 Space Syntax findings on the urban structure of Ankara. 


\section{Conclusion}

The morphological analysis of the periods affecting a capital city's urban structure is the main consideration for this paper. By focusing on the physical evaluation of the periods that affect the city's urban development in light of a mathematical method, this research aimed to define the change in the urban system.

Using Space Syntax in the analysis of Ankara's-Turkey's capital city-changing urban system contributes a striking observation about where the planning decisions in the historical process affect the city, where they continue their existence in the city, and where they have entirely disappeared. Thus, obtained results from the mathematical approach provide a distinctive determination of the strategically spatial elements or places that have a major role in being a capital city. The inferences reached from the Space Syntax analysis are shown in Figure 19. As can be seen from this inference regarding the differentiation of Ankara's physical urban system, and confirmed by Space Syntax analysis, the potential of the historical core areas of the city has shifted towards the newly developing city axis today (Figure 20).

\begin{tabular}{|c|c|c|c|c|c|c|c|}
\hline AREAS & $\begin{array}{l}\text { Before being } \\
\text { the capital city } \\
\text { (1839 Map) }\end{array}$ & $\begin{array}{r}\text { During the decl } \\
\text { of the Repu } \\
\text { (1924 Ma| }\end{array}$ & $\begin{array}{l}\text { laration } \\
\text { ublic } \\
\text { p) }\end{array}$ & $\begin{array}{l}\text { Planning Period } \\
\text { of Lörcher } \\
(1924-28)\end{array}$ & $\begin{array}{l}\text { Planning Period } \\
\text { of Jansen } \\
(1928-32)\end{array}$ & $\begin{array}{l}\text { Planning Period } \\
\text { of Yucel-Uybadin } \\
(1957-70)\end{array}$ & $\begin{array}{l}\text { Today } \\
\text { Ankara }\end{array}$ \\
\hline \multirow{3}{*}{$\begin{array}{l}\text { The highest } \\
\text { connectivity } \\
\text { value }\end{array}$} & \multirow{2}{*}{$\begin{array}{c}\text { Hakimiyet-i Milliye ULUS } \\
\text { Square }\end{array}$} & \multirow{2}{*}{$\begin{array}{l}\text { Train Station } \\
\text { Street }\end{array}$} & \multirow[t]{2}{*}{ ULUS } & \multirow{2}{*}{$\begin{array}{c}\text { Hakimiyet-i Milliye ULUS } \\
\text { Square }\end{array}$} & 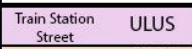 & \multirow{2}{*}{$\begin{array}{c}\text { Ziya Gökalp KIZILAY } \\
\text { Street }\end{array}$} & $\begin{array}{c}\text { Anafartalar } \\
\text { Street }\end{array}$ \\
\hline & & & & & Atatürk Boulevard ULUS & & \begin{tabular}{|c|} 
Street \\
Atatürk Boulevard KIZILAY \\
\end{tabular} \\
\hline & $\begin{array}{l}\text { Saman Bazaar } \\
\text { Koyun Bazaar }\end{array}$ & $\begin{array}{l}\text { Taceddin \& } \\
\text { Hamamänü } \\
\text { Region }\end{array}$ & ULUS & $\begin{array}{l}\text { Atatürk } \\
\text { Boulevard }\end{array}$ & $\begin{array}{cc} & \text { KIZILAY } \\
\text { Zafer Square } & \text { KIZILAY } \\
\text { Kizlay Square } & \text { KIIL }\end{array}$ & $\begin{array}{|cc|}\begin{array}{c}\text { Bahcelievler } \\
\text { Region }\end{array} & \text { WEST } \\
\text { DIRECTION }\end{array}$ & \begin{tabular}{|l} 
Bahçelievler \\
Çayyolu
\end{tabular} \\
\hline \multirow{3}{*}{$\begin{array}{l}\text { The highest } \\
\text { global } \\
\text { integration } \\
\text { value }\end{array}$} & \multirow{3}{*}{$\underset{\text { Square }}{\text { Hakimiyet- Milliye }}$ ULUS } & \multirow{2}{*}{\multicolumn{2}{|c|}{$\begin{array}{l}\text { Saman Bazaar } \\
\text { Koyun Bazaar }\end{array}$ ULUS }} & $\begin{array}{c}\text { ULUS } \\
\text { Atatürk Boulevard } \\
\text { KIZILAY }\end{array}$ & Ulus Square & Ulus Square & $\begin{array}{c}\text { ULLUS } \\
\text { Atatürk Boulevard } \\
\text { KIZILAY }\end{array}$ \\
\hline & & & & \begin{tabular}{|c|} 
Train Station \\
Street
\end{tabular} & $\begin{array}{l}\text { Tolat Pasa } \\
\text { Boulevard } \\
\end{array}$ & Kizlay Square KIZILAY & $\begin{array}{cc}\text { Konya Road } & \text { SOUTH } \\
\text { DIRECTION }\end{array}$ \\
\hline & & \multicolumn{2}{|c|}{ Taceddin Region ULUS } & $\begin{array}{l}\text { Talat Pasa } \\
\text { Boulevard }\end{array}$ & \begin{tabular}{|cc} 
Utatürk Boulevard & ULUS \\
KIZILAY
\end{tabular} & \begin{tabular}{lc|} 
Dumlupinar & WEST \\
Boulevard & DIRECTION
\end{tabular} & $\begin{array}{cc}\begin{array}{c}\text { Dumlupinar } \\
\text { Boulevard }\end{array} & \text { WEST } \\
\text { DIRECTION }\end{array}$ \\
\hline \multirow{4}{*}{$\begin{array}{l}\text { The highest } \\
\text { global } \\
\text { choice } \\
\text { value }\end{array}$} & \multirow{3}{*}{$\begin{array}{l}\text { Karaoğlan Street } \\
\text { Tahtakale Bazaar }\end{array}$} & \multirow[b]{2}{*}{$\begin{array}{l}\text { Hakimiyet-i Milliye } \\
\text { Square }\end{array}$} & \multirow{3}{*}{ ULUS } & $\begin{array}{l}\text { Hakimiyet-i Milliye } \\
\text { Square. }\end{array}$ & Ulus Square & Youth Park & \multirow{2}{*}{$\begin{array}{ll}\text { Atatürk Boulevard ULUS } \\
\text { KIZIIIAY }\end{array}$} \\
\hline & & & & Hacettepe Region ULUS & \multirow{2}{*}{$\begin{array}{l}\text { Talat Paşa } \\
\text { Boulevard }\end{array}$} & \multirow{2}{*}{ Atatürrk Boulevard KIZILAY } & \\
\hline & & \multirow[b]{2}{*}{$\begin{array}{l}\text { Train Station } \\
\text { Street }\end{array}$} & & Talat Paşa Boulevard ULUS & & & 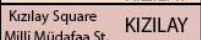 \\
\hline & Koyun Bazaar ULUS & & ULUS & \begin{tabular}{|l} 
Atatürk Boulevard KIZILAY \\
Ziya Gökalp Street KIZILAY
\end{tabular} & \begin{tabular}{|cc} 
& ULUS \\
Atatürk Boulevard & + \\
KIZILAY
\end{tabular} & $\begin{array}{c}\text { Administrative } \\
\text { Region }\end{array}$ KIZILAY & $\begin{array}{|cc|}\text { Milli Müdafaa St. } & \\
\text { Dumlupinar } & \text { WEST } \\
\text { Boulevard }\end{array}$ \\
\hline
\end{tabular}

Figure 19 Space Syntax findings of the examined different periods.

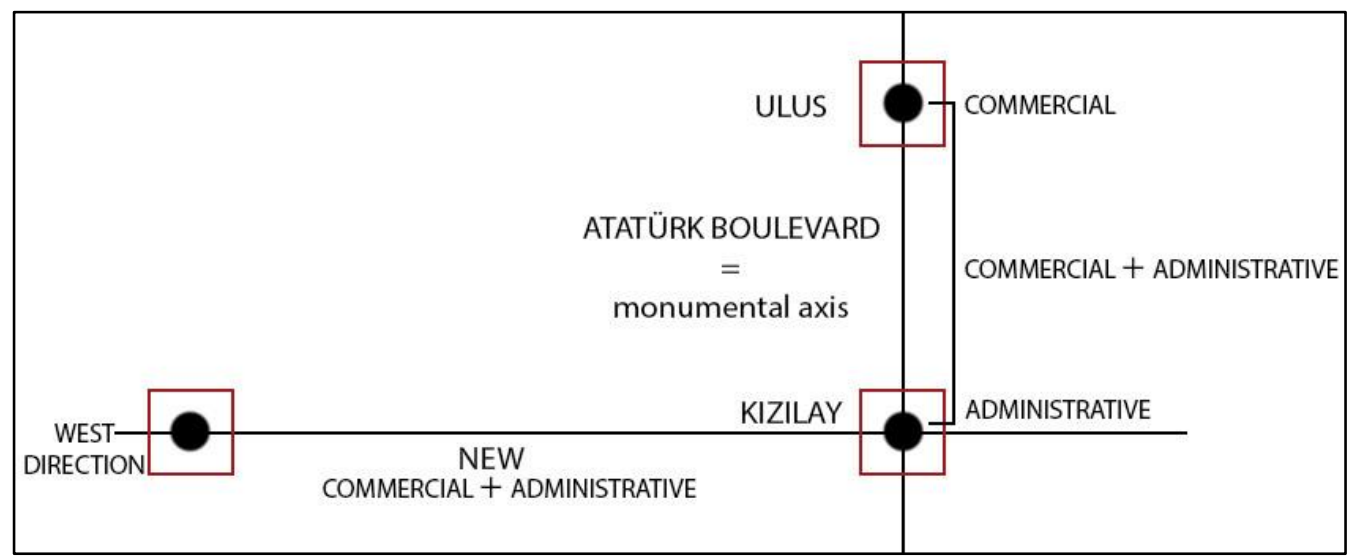

Figure 20 The schematic concluded inference about differentiated Ankara.

Economic, social, cultural, and political processes have remarkable reflections on Ankara's historical periods. By evaluating the capital city's urban system through Space Syntax, the changes caused by the mentioned effects on the morphology of Ankara are presented from a quantitative point of view. The differences between each examined period have considerable effects on the city's urban morphology and the concluded points are evaluated demonstrably. Regarding the change of the characteristics that give Ankara the role of being a capital: 
- The city is in a changing condition, and it reflects the consequences of the process on its urban form.

- Atatürk Boulevard, which formed the administrative and monumental axis of Ankara from the declaration of the Republic, came to the forefront through syntactic values in historical periods at the findings of the Space Syntax analysis. However, this special axis has lost its characteristic feature of being the main city axis today. It still exists, but the western artery of the city has strengthened its potential due to the developing political and economic demands in the new period.

- The historical core centres of the city are still carrying the potential as observed in the quantitative analysis. It is significant to preserve and move them to the future by reflecting the importance of architectural, historical, and morphological characters.

The changes in the city from historical periods to today have affected the areas that shape Ankara's urban character. This research contributes to understanding a capital city's urban development process from comparative and quantitative perspectives. By analysing the changing structure of the city analytically, the importance of morphological evaluation is highlighted in the paper.

In this study, the changing morphological structure of the capital city has been demonstrated by Space Syntax analysis. Another phase of the study has been developed through a typomorphological approach from an architectural perspective, in which the differentiation in terms of the characteristics, building materials, and heights of the buildings on the Atatürk Boulevard, which reflects the historical city, and the western direction, which reflects the new city, have been analysed. Thus, the formation and development process of a capital city is analysed on both a city and architectural scale using two different morphological methods. However, in this research, the changing process of Ankara is emphasised from a city scale using Space Syntax.

\section{References}

Al_Sayed, K., Turner, A., Hillier, B., lida, S., \& Penn, A. (2014). Space Syntax Methodology: Bartlett School of Architecture.

Ankara Metropolitan Municipality (2006). The Report of 2023 Capital City Ankara Master Plan Explanation Report.

Bayraktar, A. N. (2016). Başkent Ankara'da Cumhuriyet Sonrası Yaşanan Büyük Değişim: Modern Yaşam Kurgusu ve Modern Mekânlar. VEKAM Ankara Research Journal 4(1), 67-80.

Cengizkan, A. (2009). Ankara 1923-1938: Çağdaş Bir Ulus Devletin Modern ve Planlı Başkenti. Ankara: Kara Kalpaklı Kent. Istanbul Institute of Research Press, Istanbul, 17-64.

Günay, B. (2006). Ankara çekirdek alanının oluşumu ve 1990 nazım planı hakkında bir değerlendirme. İçinde Şenyapıll, T.(der.), Cumhuriyet'in Ankara'sı, METU Press, Ankara, 60-118.

Herbert, D., \& Thomas, C. (2013). Cities in space: city as place. Routledge.

Hillier, B. \& Hanson, J. (1984) The Social Logic of Space. Cambridge University Press, Cambridge, UK.

Hillier, B., Hanson, J., \& Graham, H. (1987). Ideas are in things: an application of the space syntax method to discovering house genotypes. Environment and Planning B: planning and design, 14(4), 363-385.

Holanda, F., Medeiros, V., Ribeiro, R., \& Moura, A. (2015, July). Brasília: Fragmented metropolis. In Proceedings 10th International Space Syntax Symposium (pp. 13-17).

Işın, E. (Ed.). (2009). Ankara: Kara Kalpaklı Kent. Istanbul Institute of Research Press, Istanbul, 11-15.

Keskinok, H. Ç. (Ed.). (2009). Cumhuriyet Devrimi'nin yolu Atatürk Bulvarı. Rekmay Press.

Kılınç, A. (2013). Seçili Başkentlerin Kent Planlama Öyküsü: Ankara, Brasilia, Canberra, Islamabad, Washington DC. ODUSOBIAD, 4(7), 17-27.

Kubat, A. S. (1997). The morphological characteristics of Anatolian fortified towns. Environment and Planning B: Planning and Design, 24(1), 95-123.

Kubat, A. S. (1999). The morphological history of Istanbul. Urban Morphology, 3, 28-40.

Kropf, K. (2017). The Handbook of Urban Morphology. John Wiley \& Sons.

Lefebvre, H. (1991). The Production of Space. Routledge. 
Malfroy, S. (2004). Can there be a joint venture between urban history and urban morphology?. URBAN MORPHOLOGY, 8, 114-114.

Rapaport, A. (1977). Human aspects of urban form. New York, 10.

Tankut, G. (1990). Bir Başkentin İmarı 1929-39. Ankara: METU Press.

\section{Resume}

Melike Boz Günay has degrees of B. Arch from TOBB University of Economics and Technology (TOBB ETU), Ankara, and MSc in Urban Design from Istanbul Technical University (ITU). She is currently working as an architect and urban designer. Her research interests are Urban Morphology, Urban Design, Space Syntax, and Typo-morphology.

Professor Ayşe Sema Kubat has degrees of B. Arch and M. Arch and PhD in Urban Design \& Urban Planning from Istanbul Technical University (ITU). She worked as a Professor at the Faculty of Architecture, Department of City and Regional Planning of ITU (1996-2020). She was the founding professor of the Landscape Architecture Department and the Interdisciplinary Graduate program at ITU. She has been serving on the Steering and Refereeing Committees of the Space Syntax Symposiums since 2003, and was the chair of the 6th International Space Syntax Istanbul Symposium in 2007. Her assistance and cooperation to the research project entitled 21st Centre of Excellence for Sustainable Urban Regeneration (cSUR) (2003- 2008) is appreciated as "Honorary Fellow of Global Center of Excellence " at Tokyo University. Her research is focused on Urban Morphology, Urban Planning \& Design, Urban History and Space Syntax. She currently serves as the "Chair of the Turkish Network of Urban Morphology TNUM" which aims to extend the cooperation between local researchers and other regional networks of ISUF (International Study on Urban Form). 